Mr. H. E. Potr's asked whether soda lind a more penetrating effect on the fibre than lime, and night not the difference be due to the difference in the surface tension induced by the lime or sodn used.

Mr. Charton Beadere replied that the alkali was washed out of the benten stuff. After beating, the fibre was able to retain a far larger quantity of water than when unbeaten. Whether that was a chemical or physical phenomenon it was difficult to say. Fighteen years ig he had made somo experiments on the rates at which desiccated cotton wool and other forms of cellulose took up water on exposure to the air. He believed that he was tho first to observe that this absorption gave rise to an increase in tempernture and that the two, namely the temperature rise and mois. ture absorption, bore some relution to one another (Beadle

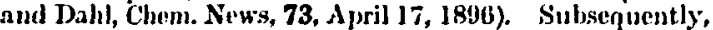
without any knowludge. of these observations, professor Orme Mlasson measured the actual heat evolved per gram of water alsorbed (''roc. Roy. Soc., 1904, 74, 2:30-254). Up to the time of tho publication of Mrsson's rescarches he (Mr. Beadle) had been inclined to regard the rise of temperature ns evidence of chemical chnnges, but Masson's conclusions were that tho amount of heat was approxi. mately that calculated for the qunntity of vapour absorbed, and that the water condensed on the cotton did not combine chemicnlly with it. That, however, still left tho explanation of "wetting" by prolonged beating or "ageing" an open question. Some regardnd it as real hydration, but athers thought that it was purely mechanical.

The beaten Hedychium became more wet and slimy to the feel, nbsorbed water and beca mo more gelatinous as the result of ageing, and simultanconsly the bursting strain of the paper produced therefrom increased. As tho material increased in wetness or hydration it beensuc more susceptible to putrefactive changes, resulting in tho des. truction of just that portion of the material which had given increased strength, hence the meloing of the initinl effects of ageing.

With rogurd to the use of soda or lime, the relative a mounts required to be used in practice was not a matter of molecular ratios. In practice it was found that 10 per cent. of lime would bring nbout a somewhat similar result to 5 per cent. of caustic soda. In the case of soda, solublo salts were olstained, whilst with lime the salts were insoluble. Furthermore, the amount of lime in solution at any ono time was small as compared with soda, and boiling with lime was a longer operation in consequence. The hydra. tion effect was greater in tho case of soda, as would be observed on comparing the two curres.

\section{THE CHEMICAL EXAMINATION OF LIQUID FUEIS.}

BY w. IIAMILTON patteirsos, M.sc.

In comparison with the enormous advances made in the mechanical application of oil as a source of power, the chemienl side of the question hus been somewhat neglected, nnd there is mach room for scientific research and investi. gation in the preparation and utilisation of fuels. 'There is also much overlapping and ambiguity in the nomenclature of the varions technical products which are put on the market as liquid fuels. I'here should be some dis. tinction botween "oil fuels" and "fuel oils." In this paper the term "fuel oil " will he reserved for oils burnt in external combustion, c.g., under a boiler for the murpose of raising steam; "oil fuels," on the other hand, will mean oils utilised for the production of power in internnl combustion engines. 'The term liquid fuel may be applied in either case.

Although many fuel oils may often be equally woll utilised as oil fuols, there is a ditference in the requir ements. In oil fuels volatility is of greater importance, and the obtaining of oils which will teither corrodo nor give tronble in the cylinders of internal combustion engines on explosion or burning. In fuel oils moro vital fact ors aro cheapness, a fairly high flash point, and high calorific value. The various liquid fucls and their allied products derived either from petroleum or conl tars are not definite compounds; it is therefore impossible to assign to these varying mixtures scientific names. It is, howover, greatly to bo doplored that, in technieal usago, tho same name is not applied in different parts of tho world to denote what is essent inlly ono and the samo product. What confusion occurs, for exnmple, in the meaning of the words, paraffin, benzine, solar oil, naphtha, etc. 'To add still further to the chaos which already exists wo find specinlly coined trado names. of oil fuels the only variety widely used for certain kinds of motor engines is petrol, but alcohol might bo used instend with equal efliciency, provided it coukl be olitained chenply enough, and also benzol, or ovon better, a mixture of the two.

TADLE I.

\begin{tabular}{|c|c|c|c|c|c|c|c|c|}
\hline No. & Description. & at $\mathbf{s p} \cdot \mathbf{s} \cdot 0^{\circ} \mathrm{c}$ & Carbon. & Hydrogen. & Sulphur. & $\begin{array}{l}\text { Oxygen } \\
\text { and } \\
\text { uitrogen. }\end{array}$ & $\begin{array}{l}\text { Net } \\
\text { calorific } \\
\text { valne in } \\
\text { calories. }\end{array}$ & $\begin{array}{c}\text { Net } \\
\text { calorifle } \\
\text { valuge ja } \\
\text { W.Th.U. }\end{array}$ \\
\hline 1 & Fuel oll used on trial of a torpedo destroyer & 0.021 & $85 \cdot 28$ & 11.93 & 0.55 & $\mathbf{2 . 2 4}$ & 0,086 & 17,975 \\
\hline & per ton $\cdots \cdots+\ldots \ldots \ldots \ldots \ldots \ldots \ldots$. & $(0.888)$ & $80 \cdot 20$ & $12 \cdot 6 \pi$ & $0 \cdot 31$ & 0.02 & 10,007 & 38,175 \\
\hline 3. & Ordinary crube petroleum $\ldots \ldots \ldots \ldots \ldots \ldots$ & 0.023 & - & - & 0.45 & - & (IIydrogen & 17,021 \\
\hline t. & " Light tuel oll " ...................... & at $18^{\circ} \mathrm{C}$ & $88 \cdot 58$ & $20 \cdot 81$ & $0 \cdot 43$ & 0.18 & $10,13 \%$ & 38,405 \\
\hline 5. & 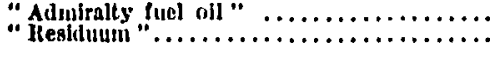 & $\begin{array}{c}0 \cdot 028 \\
(0 \cdot 9+3) \\
0 t+18^{\circ} \mathrm{C} .\end{array}$ & $\begin{array}{l}80 \cdot 40 \\
80 \cdot 44\end{array}$ & $\begin{array}{ll}11+5.5 \\
11 \\
11\end{array}$ & $\begin{array}{l}0.34 \\
0 \cdot 30\end{array}$ & $\begin{array}{ll}1 \cdot 71 \\
210 ;\end{array}$ & $\begin{aligned} 9,001 \\
10,040 ;\end{aligned}$ & $\begin{array}{l}17,030 \\
18,177\end{array}$ \\
\hline ק. & 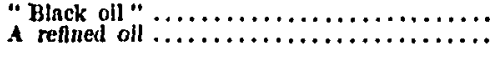 & $\begin{array}{c}0 \cdot 028 \\
(0 \cdot 00+1) \\
0 t+8^{\circ} \mathrm{C} .\end{array}$ & $\begin{array}{l}80 \cdot 44 \\
85.05\end{array}$ & $\begin{array}{l}11 \cdot 83 \\
12 \cdot 15\end{array}$ & $\begin{array}{l}0 \cdot 51 \\
0.37\end{array}$ & $\frac{1 \cdot 29}{2 \cdot 43}$ & 9,077 & $\begin{array}{l}17,050 \\
17,0905\end{array}$ \\
\hline o. & A Roumanian criule oll $\ldots . . . \ldots \ldots \ldots . . .$. & 0.825 & - & - & 0.20 & - & $\mid \begin{array}{c}0,024 \\
\text { (11 assutued } \\
13 ;(1) \%)\end{array}$ & 17,803 \\
\hline 10. & Solar ofl (Texns) $\ldots \ldots \ldots \ldots \ldots \ldots \ldots \ldots \ldots \ldots \ldots$ & $\begin{array}{c}0.830 \\
(10.80: 2)\end{array}$ & $\begin{array}{l}83 \cdot 77 \\
85 \cdot 35\end{array}$ & 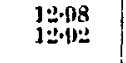 & $0 \cdot 29$ & 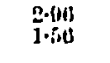 & $\begin{array}{l}10,01: 2 \\
10,101\end{array}$ & 18,022 \\
\hline 12. & Scottlsh shale ofl $\ldots \ldots \ldots \ldots \ldots \ldots \ldots \ldots$ & 0.855 & $80 \cdot 10$ & $1: 37$ & $0 \cdot 20$ & $1 \cdot 21$ & 10,138 & 18,248 \\
\hline 13. & 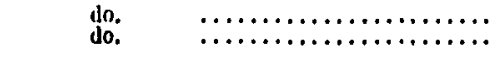 & $0.86 \%$ & $85 \cdot 3 i$ & $12 \cdot 44$ & 0.090 & 1.74 & $\begin{array}{c}10.170 \\
0,061 \\
(11) \text { aksumed }\end{array}$ & $\begin{array}{l}18,317 \\
17,030\end{array}$ \\
\hline $\begin{array}{l}17 . \\
10 . \\
17 .\end{array}$ & 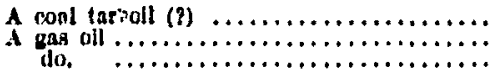 & $\begin{array}{l}0.908 \\
1.067 \\
i \cdot(001\end{array}$ & $\begin{array}{l}86 \cdot 10 \\
87.6 \pm \\
83.72\end{array}$ & $\begin{array}{l}0.06 \\
5.98 \\
7.20\end{array}$ & $\begin{array}{l}0.80 \\
0.137 \\
0.82\end{array}$ & 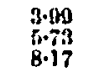 & $\begin{array}{l}0,42,2 \\
8,874 \\
8,870\end{array}$ & $\begin{array}{l}10,000 \\
16,303 \\
16,07 \%\end{array}$ \\
\hline
\end{tabular}


When, however, liquid fuels have to compete with coal for the production of power, only crude products, by-products, or residues can be considered. Tho available sources of such liquid fuels may be divided as follows :-

(1) Crude petroleum or residues and products from petroleum.

(2) I'ar oils from conl distillation, coking or producer plants, especially from bituminous conl producers.

(3) Jiquits or oils from vegetuble or numal sources including uleohol and nut oils (at the present time of little imprortance).

(t) Oils from lignite, pent, woot, or slinle.

The last class is not very important as far us this count ry is concerned, exeept as rugards the Seottish oil production from shale, which amounts to about 70 million gallons per annum. This figuro includes, however, a largo percentage of constituents too valuables to be utilised as ordinary liquid fuel. The following results have been obtained in the exnmination of various liquid fuols, most of which are available in this country and obtainable at the cheapest price: tho highest prico (i.e., at the timo of the nxperiments) in any case in this country being a little over $\mathrm{e} 3$ por ton, nost of them, however, being considerably cheaper. They have been examined moro particularly with reference to their use us oil fuels. The calorific values were determined by tho Mnhlor homb calorimeter, a method which gives absolutely reliable results when worked under proper conditions, The sulpluc was determined ly titration of tho bomb liquid, allowance being made for the nitrie acid produced in each case. Curbon und hydrogen were determined by the ordinary combustion method of elementary organic anulysis.
Open tests were made of flashing and burning points, while viscosity was determined in a special viscometer. Tho mnin figures nre tabulated in linble $I$.

Of these oils, Nos, 3, 11 and 14 have been found to work well on Diesel engines, and there is good reason to suppose that Nos. $1,2,5,7,8,12,13$ and 14 would work equally w'ell.

Nos. 16 and 17 have been found to give trouble with Diesel engines. As fuel oils probably all the oils tubulated would give an efficiency proprortional to their uet calorific value. It will further be seen that the sulphur content is in no case exceswive. The much lower calorilic values of oils Nos. 16 and 17 may arceunt in somo measure for the trouble they give in Dienel engines, but there are of her factors which are brought out in the tables below. III combustion of fuels in the bomb colorineter, the products of combustion are cooled to the ordinary temperuture of the culorimeter; the hydrogen of the fuel is oxidisted to water which gives up its latent hent on condensation. 'Thore is also in small anount of sulphuric and nitric ncids produced which must be nllowed for. The heat value actually obtained in the bomb calorimeter is the gross value, while that corrected for hydrogen and acid formation is the net value, and corresponds to the mnximum energy of the fuel which is nvailable for the production of work in ordinnry practive. It is nstonishing how in ordinary com. mercial practice the two values are confused. 'l'o npply the right correction for the water condensed, it is necessary to know the hydrogen in the oil (also the freo water if there is any present). 'To ascertain the correction diwe to the former cause, the only absolutely reliable means is to determine tho hydrogen by making an elomentary unalysis of the oil. This is, however, a tedions process and in most cases, as will be show'n below, the hydrogen content may be assumed with an accuracy gufficient for the purpose of applying this correction in technical work.

I'AnI.E: II.

\begin{tabular}{|c|c|c|c|c|c|c|c|}
\hline Xo. & Open thash polnt, & Burning poist. & Hydrogen. & $\begin{array}{c}\text { Gross calorific } \\
\text { valus } \\
\text { (In calories). }\end{array}$ & $\begin{array}{l}\text { Hyolrogen } \\
\text { correct fonl. }\end{array}$ & $\underset{\text { correctlon. }}{\text { Acid }}$ & $\begin{array}{l}\text { Net cnlorific } \\
\text { value. }\end{array}$ \\
\hline $\begin{array}{l}1 . \\
2 . \\
3 . \\
4 . \\
5 . \\
6 . \\
7 . \\
8 . \\
0 . \\
10 . \\
11 . \\
10 . \\
13 . \\
10 . \\
10 . \\
17 .\end{array}$ & $\begin{array}{c}133^{\circ} \\
125^{\circ} \\
195^{\circ} \\
180^{\circ} \\
138^{\circ} \\
100^{\circ} \\
145^{\circ} \\
130^{\circ} \\
\text { Orlinary temn. } \\
\text { Ordinary temp. } \\
900^{\circ} \\
120^{\circ} \\
130^{\circ} \\
130^{\circ} \\
77^{\circ} \\
90^{\circ} \\
70^{\circ}\end{array}$ & $\begin{array}{c}164^{\circ} \\
147^{\circ} \\
156^{\circ} \\
240^{\circ} \\
163^{\circ} \\
107^{\circ} \\
179^{\circ} \\
135^{\circ} \\
\text { Orinaiy temp. } \\
\text { Orinary temin. } \\
07^{\circ} \\
158^{\circ} \\
150^{\circ} \\
148^{\circ} \\
106^{\circ} \\
109^{\circ} \\
80^{\circ}\end{array}$ & 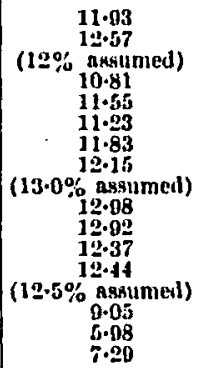 & 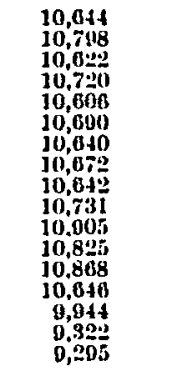 & 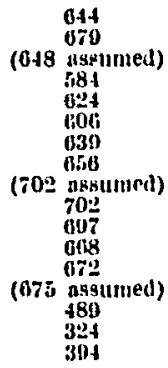 & $\begin{array}{l}1+(\operatorname{totn}) \\
15+7 \\
8+10 \\
13+9 \\
13+8 \\
12+7 \\
12+12 \\
10+8 \\
12+4 \\
11+0 \\
10+4 \\
13+6 \\
13+7 \\
3+7 \\
0+24 \\
8+16 \\
7+18\end{array}$ & $\begin{array}{r}9,986 \\
10,007 \\
9,056 \\
10,114 \\
9,901 \\
30,005 \\
0,077 \\
9,008 \\
9,024 \\
10,010 \\
10,191 \\
10,138 \\
10,176 \\
0,901 \\
9,492 \\
8,074 \\
8,870\end{array}$ \\
\hline
\end{tabular}

TanLE III.

\begin{tabular}{|c|c|c|c|c|c|c|c|c|c|c|c|}
\hline \multirow[b]{2}{*}{ No. } & \multirow{2}{*}{$\begin{array}{l}\text { Net } \\
\text { mulorlite value. }\end{array}$} & \multirow{2}{*}{$\begin{array}{l}\text { Cuilculntesl } \\
\text { vulue. }\end{array}$} & \multirow[b]{2}{*}{ Ditfresuce. } & \multicolumn{8}{|c|}{ Percentage sroctionated. } \\
\hline & & & & $80^{\circ} \mathrm{C}$ & $120^{\circ}$ & $160^{\circ}$ & $200^{\circ}$ & $240^{\circ}$ & $280^{\circ}$ & $3 \mathbf{2})^{\circ}$ & $300^{\circ}$ \\
\hline J. & 0,084 & 10,300 & $+34 t$ & - & - & - & n) & 3 & 15 & 34 & ist \\
\hline$\ddot{\ddot{z}}$ & 10,138 & $10, \sqrt{10} \geq 01$ & & - & - & 0 & 8 & 10 & 20 & 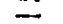 & - \\
\hline 4. & ili,11t & 10,316 & $+ \pm(0 i$ & - & 一 & - & - & - & 0 & 1.2 & all \\
\hline i. & B.gui & 10, $214 f_{2}$ & +344 & - & - & - & - & - & 14 & 40 & 71 \\
\hline i. & $10,0 \mathrm{HBS}$ & j0. $103^{\circ}$ & $+1 \pm 8$ & - & - & - & - & - & d & 20 & is \\
\hline 7. & 0,077 & 30.401 & +124 & - & - & - & - & 4 & II & 31 & - \\
\hline 8 & 0,498 & 10, $343 \pi$ & +337 & $\rightarrow$ & $\bar{F}$ & $\overline{1}$ & $\bar{\pi}$ & $1 i$ & 63 & 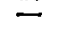 & - \\
\hline 10. & (10,010 & jo, 450 & $+\operatorname{tis}$ & (1) & 17 & $\$ 1$ & 41 & 41 & 67 & - & - \\
\hline 11. & 10,191 & 10,008 & ++17 & - & - & 0 & iI & is & (4) & $=$ & - \\
\hline iï. & 10,138 & $00,5=40$ & +301 & $=$ & - & - & - & 0 & 10 & i1 & - \\
\hline $\mathrm{i} \overrightarrow{\mathrm{j}}$. & 10,170 & $30,+70$ & $+30 \mathrm{x}$ & - & - & - & (1) & 7 & 28 & - & - \\
\hline if. & 0.402 & 0,474 & +60 & - & 0 & t & 8 & 20 & $\because$ & - & - \\
\hline 16. & 8,074 & 8,039 & -\$\$3: & - & 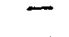 & $1, \overline{80^{\circ}}$ & "it & 40 & nth & - & - \\
\hline 17. & 8,870 & 8,020 & -260 & - & - & 1is & 48 & $\{813\}$ & - & - & - \\
\hline
\end{tabular}


In Table II. the figures aro given for tho open flash points, burning points, hydrogen contents, gross calorific value given by the bomb calorimeter determina. tion, the watgr correction for the hydrogen, the acid correction in the orier nitric acid +sulphuric acid, and tho corrected or net calorific value.

In low boiling fractions of potroleum products, tho hydrogen content mny reach 16 per cent. or more.

It is of interest to maleulate the calorific values from the results of analysis and to compare them with those actually obtained by the ealorimeter. For this purpose, the fierman modifiention of tho Dulong fommla is used, i.r., $810+290\left(11-\frac{0+N}{8}\right)+2.5-6 W$, a formula which gives results in the enst of ordinary conl, within 1 per cent. of the actual. It is not meant to be impliet thit this formula is strictly applicable to oils, but if it is applied, the differenees are instruetive. Applying this to the vils above, figures are given in Table IIt.

Figures for fractionation are also nppended.

Curres plotted to show the ehnnge of riscosity with tomperature show very sudden rises in viscosity at tho low temperature end of the curve. For instance, viscosity figures for No. 2 aro :-

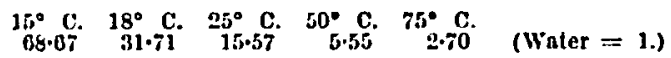

At the low temuerature end of the curve, $0.1^{\circ} \mathrm{C}$. makes a very marked difference in the time of flow. This is of importance when oils are to be used on intornal combustion eugines. The Diesel engine can take an oil which will not visibly flow at ordinary temperature, if the oil has been subjected to a preliminary heating. On the other hand, it is possible to have an oil ton mobile, which gives tronble by leaking throngh the valves. If an engine is taking feed at motemperature where the viscosity curve for the par. ticular oil used is steep, trouble will probably ho caused by the slight temperature variations making such a marked rlifference in the rate of flow of the oil.

A curve plotted to show the pereentage fractionated at various temperatures shows a steep initial rise in No. 2 and a wave surface with two crests in the cases of Nos, 9 and 10, but the rest do not diffor widely from straight lines of varying inclinations to the ordinates.

'The tables above bring out in sharp contrast the dis. tinction between products which linve petroleum for their origin and those which have coal. This is especinlly noticeable in the case of the differences between netunl and calculated calorific values which are negative in the latter cast.

'I'he two products are untirely different in all their pro. perties, typical mainly of the differences between saturated and cyclic hydrocarlions.
No. 1 fractionated gave the following results :Carbon. Hydrogen per cent. per cent.

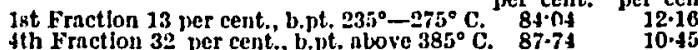
(or restane)

In the latter case there was some free carbon.

'Iaking petroleum products by themselves, there is a general relntionship between low specific gravity, low tlash point, high hydrogen content, low boiling point, and conversely between high specific gravity, high flash point. low hydrogen content and high hoiling point; but, as is to be expected in such a complex and varying substance, a mixture of muy distinct chomical compounds, no absolute relutionship can lie traced.

\section{Disi:usstos.}

Mr. J. 'Twonks asked if the nuthor conld recommond a sutisfactory empirical formula for the estimation of the hydrogen in conl.

Mr. Craxzos Beanle asked if tho author could explain the fact that the differences between the calculated and experimental values were positive in all cases of the oils, except the linst two on the table.

Professon Dossax asked what was the trouble in the Diescl engine referred to. Was it due to formation of carbon? What oils, other than petrol, could be used in engines of tho motor-car type; also how far could the conl-tar oils referred to compare with petrol ?

Mr. H. E. Potrs asked how the sulphur was estimated in the various oils. Personally he found that the addition of alkali chloride to four times the amount of the nitrate present was advisalule to givo accurate results.

Professor BAIY asked whetler any work had been done with the use of "cracked oils" in engines of the Diesel type. Would it not be possible to carry such oils in cylinders and use them in internal combustion engines? Ho imagined that those oils were very cheap, and thoy burnt very ensily.

J). J. Harores asked if the aut hor had had any experience with coal tar oils distilled from coal at low temperntures, such as $400^{\circ} \mathrm{C}$. It secus as if the supply of fucl for motorcar engines, etc., in the future must lie in this direction.

Mtr. Pattersos, in reply, said he only knew of one formula for estimating hydrogen in oils, and that connected specific gravity with hydrogen content. Tho figures he had given showed what very false results that would lead to. The trouble referred to in internal combustion engines was generally due to deposition of earbon. Sulphur was estimated by double titration of the bomb liquid by barium hydroxide and sodium carbonate; this method only occupied about ten minutes. He did not think that the " cracking process" was earried out to any great extent. Either the lowering of boiling point was not greatly nitered thereby, or clse, if it were so, the qunntity of oil so trasis. formed was relatively small. He had no experience with oils made by distillation of conls at low temperatures.

\section{Journal and Patent Literature.}

Yatrxt SpectFicatioss may bo obnined by post by remitting an followa :-

English.-8d. each, to the Comptroller of the Patent Onice, W. T'emple Franks, Bag., Soutlampton Builings, Chancery Lane, Joindon, W.C.

Onited States.-1s, encli, to the Secretary of tho soejety.

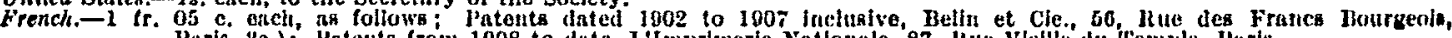

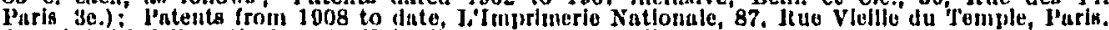

German.-1 mark each (witl, full particulars) to Kalserlicli l'atentant, Herlin, Germans.

\section{I.-General PLANT; MAChineRY.}

\section{Patents.}

Drying apparulus. C. Wille, I'empelhof, Germany. U.S Pat. 1,051,35!, Jan. 21, 1013.

'Lu: apparatus consist of a donble.walled drying drum inounted to rotate horizontally within a trough, the wholo leing enclosed in a ehnmber provided with heaters, Conveyor-deviees aro mounted on the exterior of the drum-which, if not of polygomal eross-sect ion, is provided internally with ehnins extending ulong its whole longth for the purpose of bringing the charge into intimate contact with the heated air-and suitable provision is mado for the eireulation of heated air through and aromed the drum.-W. E. W. P. 